\title{
Neke smjernice za pastoral braka i obitelji prema apostolskoj pobudnici Amoris Laetitia (II.)
}

\author{
IVAN ŠARČEVIĆ* \\ - https://doi.org/10.31823/d.29.2.2 • \\ UDK: 27-45-555 - Izvorni znanstveni rad \\ Primljeno: 8. travnja 2020. Prihvaćeno: 27. svibnja 2021.
}

Sažetak: Drugi dio članka »Neke smjernice za pastoral braka i obitelji prema apostolskoj pobudnici Amoris Laetitia koncentrira se na pastoralne smjernice koje proizlaze iz pobudnice Amoris laetitia, a koje se odnose na savjesno razlučivanje okolnosti u kojima nastaju problemi i rastave te na integriranje ostavljenih, razvedenih i rastavljenih u crkvenu zajednicu. Tako se razmatra važnost pojma razlučivanja i njegova slojevitost te različiti tipovi razlučivanja. Drugi dio, posvećen integriranju u zajednicu, želi izložiti integriranje u zajednicu u širem kontekstu te također prikazati osnovne konture i složenost takvoga procesa.

* Prof. dr. sc. Ivan Šarčević, Franjevačka teologija Sarajevo, Aleja Bosne Srebrene 111, 71000 Sarajevo, Bosna i Hercegovina, ivansarst@gmail.com

Ključne riječi: obitelj, ljubav, Bog milosrda, Crkva izlaska, savjest, pastoral praćenja i razlučivanja.

\section{Milosrdno razlučivanje kao metodološki korak}

Tri temeljne riječi dviju sinoda i same pobudnice jesu pratiti, razlučivati i integrirati. Posebno je pojam razlučivanje, kao drugi metodološki korak za pastoral braka i obitelji, izazvao raspravu i konflikt interpretacija. Pobudnica Amoris laetitia navodi glagolsku imenicu razlučivanje 27 puta, u naslovima tri puta i u podnožnim bilješkama dva puta; a glagol razlučivati sedam puta u tekstu i dva puta u naslovima, od kojih je jednom u naslovu VIII. poglavlja (Pratiti, razlučivati $i$ integrirati slabosti). ${ }^{1}$ Tako česta upotreba toga

${ }^{1}$ Usp. A. DONATO, Il discernimento pastorale misericordioso, u: G. Del MISSIER, A. G. FIDALGO (ur.), Amoris laetitia. Il Vangelo 
termina govori o njegovoj važnosti, iako se nigdje ne daje precizna definicija. No dokument pruža neke specifikacije toga termina iznimno važna za pastoral.

Razlučivanje je dakle ključna riječ apostolske pobudnice Amoris laetitia (AL). Papa Franjo ne koristi se tim pojmom toliko $\gg$ u značenju sposobnosti smislenoga suda, što se veže uz klasično poimanje krjeposti razboritosti «, koliko »u tehničkom značenju svojstvenom duhovnosti, pa bi razlučivanje bilo sposobnost ostvarenja vlastite slobode u donošenju odluka, posebno onih koje se odnose na identifikaciju sredstava da se dosegnu postavljeni ciljevi $\ll^{2}$. Razlučivanje se odnosi na savjest i na povijesnost, s nakanom da se - kako već na početcima pobudnice stoji - ne upadne $\mathrm{u}$ apstrakciju, teoretiziranje i idealiziranje braka. ${ }^{3} \mathrm{Za}$ papu Franju razlučivanje nije samo » rezultat « nego put, proces, metoda mišljenja i djelovanja, zato i kažemo da je korak u njegovoj pastoralnoj metodologiji, koji dovodi do uvijek otvorena isho$\mathrm{da}, \mathrm{k}$ onom većem i višem što Bog od nas traži. I nije riječ samo o biranju jedne, a odbacivanju druge stvari, o pitanju izbora između dobra i zla, nego i o razlučivanju između dvaju ili više dobara te o odlučivanju za ono što se najviše sviđa Bogu. Osim uvažavanja osobnoga razlučivanja, s pravom $\mathrm{D}$. Fares naglašava da je razlučivanje za papu Franju povezano i s inkulturacijom, s različitim kontekstima krajevnih Crkava. Ono je metoda inkulturacije evanđelja, štoviše, izjednačuje se s inkulturacijom. ${ }^{4}$

Razlučivanje je duhovna realnost i ne iscrpljuje se u sociološkoj i psihološkoj analizi. ${ }^{5}$ Ono je Božji nadnaravni dar. ${ }^{6}$ Čini se u svjetlu vjere, pod kriterijem Božje riječi,

dell'Amore: un cammino da intraprendere..., Padova 2018., 68-69. M. Ometto piše da se ključni termin razlučivanje (u tal. discernimento) pojavljuje 41 put (usp. M. OMETTO, Divorziati che vivono una nuova unione nella Chiesa cattolica. Da Familaris consortio ad Amoris laetitia, Canterano (RM), 2018., 245.).

${ }^{2}$ M. OMETTO, Divorziati che vivono una nuova unione nella Chiesa cattolica, 245., bilj. 119.

${ }^{3}$ Usp. AL, br. 36. Spadaro se posebno osvrće na termin razlučivanje. Ističe također da je naslov pobudnice papa Franjo uzeo od Benedikta XVI. iz njegova motuproprija Porta Fidei, za godinu vjere (usp. A. SPADARO, Introduzione: Amoris laetitia. Struttura e significato dell'Esortazione apostolica postsinodale di Papa Francesco, u: FRANCESCO, Amoris laetitia. Esortazione apostolica postsinodale sull'amore nella famiglia, Milano, 2016., 5-32.

${ }^{4}$ Usp. D. FARES, Amoris laetitia e il rinnovamento del linguaggio ecclesiale, u: FRANCESCO, Amoris laetitia, 238.

${ }^{5}$ Usp. L. MARTÍNEZ SISTACH, Come applicare l'Amoris laetitia, 2016., 73. U prosudbi stvarnosti i društvenih odnosa teologiji oslobođenja zamjeralo se korištenje marksističkoga sociološkoga instrumentarija.

${ }^{6}$ U apostolskoj pobudnici Radujte se i kličite, o pozivu na svetost u suvremenom svijetu, Papa će još preciznije izraziti kako shvaća razlučivanje: »Istina je da duhovno raspoznavanje [razlučivanje] ne isključuje korištenje ljudskog znanja, onoga egzistencijalnog, iz psihologije, sociologije i morala. No, ono ih nadilazi. Isto tako nisu dostatne samo mudre norme Crkve. Sjetimo se uvijek da je razlučivanje milost « (FRANJO, Gaudete et exsultate, Zagreb, 2018., br. 170). 
u osluškivanju tradicije i iskustva drugih. Dakle razlučivanje je dijaloški proces, ne neka privatna radnja, ali i eminentno osobni put mišljenja, djelovanja - na koncu, samostalna i slobodna odluka pojedinca. Odluka koja je prošla kroz slušanje argumenata bližnjih i prijatelja, ali i onih koji ne dijele naše stavove i onih koji su protiv nas jer istinsko razlučivanje upravo uviđa da nisu svi protivnici i neprijatelji niti je svako prijateljsko mišljenje zaista prijateljsko.

Razlučivanje se primarno odnosi na ono najteže u vjeri - razlučivanje Božje volje u konkretnoj situaciji od raznih vlastitih želja, slabe ili zle volje, od željâ i voljâ poglavarâ i kolektiva. Usto razlučivanje nije jednokratan čin, kao jednom smo se za nešto odlučili i mislimo da smo svoj put odluka završili, nego je to proces, životni proces $^{7}$ trajnoga odgonetanja Božje volje, kao i odricanja od drugoga, ne uvijek negativnoga i lošega, nego i manje dobroga. Razlučivanje je nadilaženje onoga čemu smo tako rado skloni i prilagodljivi i kretanje prema višem, savršenijem, svetijem, a što je uvijek odluka za teže.

Uz praćenje supružnika i obitelji, uz integriranje u crkvenu zajednicu razlučivanje je sastavni dio (drugi korak) u pastoralu braka i obitelji, posebno kada nastanu problemi i krize. Spominje se ponajviše u pastoralnim dijelovima pobudnice, u VI. poglavlju (osobito pod naslovom: Unositi svjetlo u krize, tjeskobe i teškoće, br. 231-252) i u VIII. poglavlju (br. 291-312). ${ }^{8}$ Amoris laetitia u poimanju pastorala, a time i razlučivanja, nastavlja se na Franjinu programsku pobudnicu Evangelii gaudium te ju ponavlja (usp. br. 20-24, 25-33). I ovdje se govori o Crkvi koja izlazi i traži ljude, >s poniznošću i suosjećanjem « ${ }^{9}$. Papi je iznimno stalo da se Crkva i iznutra preobrazi evangelizacijskim misijskim poslanjem i pastoralnim radom. ${ }^{10}$

Unutar misionarskoga koncepta Crkve i pastoralne brige za ljude treba razumjeti kategoriju razlučivanja. Ono ne znači tvrdokorno slijediti ono što mi odgovara i što

\footnotetext{
${ }^{7}$ Razlučivanje nije dijagnoza koja pronalazi patologiju i lijek za ozdravljenje, nije ni problem solving koji uključuje racionalne rezerve da se nađe rješenje problema, kao što je i kazuistika koja se bazira na moralnom razrješenju pojedinoga slučaja imajući u vidu moralno načelo po koje treba podvesti pojedini slučaj. $\gg$ Temeljna pretpostavka razlučivanja nije u tome da se odnosi na problem, nego više na život na putu, na osobu koja ide stazom prema Bogu. Dakle razlučivanje određuje etape i dimenzije hoda da se prepozna gdje i kako Bog poziva osobu ili zajednicu na obraćenje i na život « (A. SPADARO, L. J. CAMELI, La sfida del discernimento in Amoris laetitia, u: FRANCESCO, Amoris laetitia, 247.).

${ }^{8}$ Ovdje je i najviše podnaslova s pojmom razlučivanje: Razlučivanje takozvanih $\gg$ neredovitih situacija (br. 296-300), Ublažavajuće okolnosti u pastoralnom razlučivanju (br. 301-303), Propisi i razlučivanje (br. 304-306).

${ }^{9}$ AL, br. 200.

$10 \gg$ Nadam se da će sve zajednice uložiti potrebna sredstva da napreduju na putu pastoralne i misijske preobrazbe, koje ne može ostaviti stvari takve kakve jesu « (EG, br. 25).
} 
mi se sviđa, nego podrazumijeva razborito sagledavanje svoje situacije i situacije drugih u svjetlu Božje riječi i povrh svega pod kriterijem Božje milosrdne ljubavi prosuđivati različitost osoba, složenost okolnosti i stupnjeve odgovornosti. Razlučivanje čini čovjeka samostalnim i slobodnim, odvažnim i zrelim. Implicira slijeđenje vlastite savjesti, dobro formirane. U savjesti se naime oblikuje sposobnost i moć razlučivanja. Teolozi Spadaro i Cameli tumače Papino poimanje savjesti kao intimno susretište pojedinca s Bogom, kao mjesto slušanja i razgovora, razlučivanja i donošenja najvažnijih odluka.

$\gg$ Cilj razlučivanja - prema Pismu i tradiciji, odakle aktualni papa zahvaća širokim rukama - jest spoznati Božju volju u pojedinačnim okolnostima vlastitoga života, tako da je se prihvati i po njoj živi na najbolji mogući način. Hipoteza je - i to je vrlo važno za razumijevanje razlučivanja - da ne postoji samo 'opća' ili univerzalna Božja volja, nego također posebni i jedincati način kojim je Božja volja opečatila moj život mojom osobnošću, mojim okolnostima i mojim jedincatim pozivom. To shvaćanje posebnosti kršćanskoga puta evidentno je u cijeloj Amoris laetitia $\ll{ }^{11}$, zaključuju spomenuti autori.

Razlučivanje se, prema pobudnici, najviše odnosi na pitanje krivnje, odnosno odgovornosti osoba u situacijama bračnih i obiteljskih kriza, rastava i razvoda te mogućnosti stupanja u novo zajedništvo i primanje sakramenata. Polazeći od raznolikosti konkretnih situacija, najprije je važno istaknuti da se, prema Papinim riječima, »ni od Sinode ni od ove pobudnice « ne bi smjelo očekivati

»nova opća pravila crkvenopravne naravi, koja se mogu primijeniti na sve slučajeve. Ono što je moguće jest jednostavno ponoviti poticaj [u izvorniku stoji: un nuovo inocoraggiamento] na odgovorno osobno i pastoralno razlučivanje pojedinih slučajeva, u kojem će se prepoznati da, budući da se 'stupanj odgovornosti razlikuje od slučaja do slučaja', posljedice ili učinci nekog pravila ne moraju nužno uvijek biti isti. ${ }^{12}$ Prezbiteri

\footnotetext{
${ }^{11}$ A SPADARO, L. J. CAMELI, La sfida del discernimento in Amoris laetitia, 245-246.

${ }^{12} \mathrm{Na}$ tom mjestu, u bilješci 336., upozorava se na sakramentalnu disciplinu tako da se razlučivanjem $\gg$ može ustanoviti da u određenoj situaciji nema ozbiljne krivnje «. Poziva se na Evangelii gaudium br. 44 u kojem se citira Katekizam Katoličke Crkve o pitanju ubrojivosti i odgovornosti za neki čin: »Ubrojivost i odgovornost za neki čin mogu se umanjiti ili poništiti neznanjem, nepažnjom, nasiljem, strahom, navikama, neumjerenim strastima i drugim psihičkim ili društvenim čimbenicima « (Katekizam Katoličke Crkve, Zagreb, 1994., br. 1735). Papa zatim nastavlja u Evagelii gaudium: »Svećenike podsjećam da ispovjedaonica nije soba za mučenje, već mjesto susreta s milosrđem Gospodina koji nas potiče da učinimo ono što je u našoj moći. Mali korak, usred velikih ljudskih ograničenosti, može biti Bogu ugodniji od izvana gledano ispravnog života onoga koji u svojem životu ne nailazi na veće
} 
imaju zadaću 'savjetovati te osobe u odgoju za razabiranje, u skladu s naukom Crkve i biskupovim smjernicama' $\ll{ }^{13}$.

Slijedi zahtjev ispitivanja savjesti uz pokoru. Rastavljeni se trebaju pitati, što je također jedan vid razlučivanja, kako su se odnosili prema djeci, kako su se ponašali prema ostavljenom bračnom drugu, »koje su posljedice novog odnosa na ostatak obitelji i zajednicu vjernika, te kakav primjer njihov odnos pruža mladima koji se tek pripravljaju za ženidbu $\ll^{14}$. Pobudnica ne dopušta površno i olako prihvaćanje rastava i novih bračnih odnosa, nego istančano razlikovanje odgovornosti za visoki ideal bračne i obiteljske ljubavi i zajedništva.

\subsection{RAZLIČITE OKOLNOSTI - RAZLIČITA RAZLUČIVANJA}

Prema pobudnici Amoris laetitia, postoje različiti tipovi razlučivanja (negdje se u našem prijevodu discernimento prevodi i s glagolskim imenicama razabiranje ili rasudivanje). Vrijedi poći od temeljnoga shvaćanja razlučivanja po kojem sklapanje ženidbe i odluka za brak s konkretnom osobom nije, kako kaže pobudnica, puki društveni, ugovorni čin, nego ima veze s Bogom. Ženidba je, zapravo, odgovor na Božji poziv, a bračni drug jest Božji dar. Mogli bismo riječima redovnoga iskustva potvrditi da mnogi zaručnici na početku svoje veze jedno drugomu i kažu: $P a$ sam te je Bog meni poslao! Sakramentu ženidbe trebalo bi prethoditi razlučivanje zvanja - je li konkretni bližnji, ta i ta osoba, Božji poziv meni da ga prihvatim kao dar i zadaću pa da s tom osobom zasnujem obitelj i s njom živim čitava života. U pobudnici točno piše: »Sakrament ženidbe nije društveni ugovor, prazni ritual ili samo vanjski znak opredijeljenosti«, nego je »dar za posvećenje i spasenje suprugâ, jer pripadajući jedno drugome, oni doista, sakramentalnim znakom, uprisutnjuju odnos Krista i s njegovom Crkvom $\ll^{15}$. »Brak je zvanje, budući da je odgovor na odre-

teškoće. Svi imaju potrebu da ih dotakne utjeha i poticaj spasenjske ljubavi Boga koji na tajanstven način djeluje u svakoj osobi, bez obzira na njezine mane i njezine padove (EG, br. 44).

A nakon što u broju 46 pobudnice EG govori o Crkvi izlaska i otvorenih vrata da bi se došlo do ljudskih periferija, u br. 47 piše: »Crkva je pozvana da uvijek bude Očev otvoren dom. (...) Svi mogu sudjelovati na neki način u crkvenom životu, svi mogu biti dio zajednice pa se ni vrata sakramenata ne bi smjela zatvarati jednostavno iz bilo kojeg razloga. To vrijedi prije svega kada je riječ o onom sakramentu koji je 'vrata' - krštenju. Euharistija, premda predstavlja puninu sakramentalnog života, nije nagrada za savršene, već velikodušan lijek i hrana za slabe. Ta uvjerenja imaju također pastoralne posljedice koje smo pozvani mudro i odvažno razmotriti. Često se ponašamo poput kontrolora milosti, a ne kao njezini omogućitelji. No Crkva nije carinarnica, ona je očev dom, gdje ima mjesta za svakoga s njegovim tegobnim životom.«

${ }^{13}$ AL, br. 300.

${ }^{14}$ Isto.

${ }^{15}$ AL, br. 72. 
đeni poziv na življenje bračne ljubavi kao nesavršenoga znaka ljubavi između Krista i Crkve. Prema tome odluka o sklapanju ženidbe i zasnivanja obitelji treba biti plod procesa razlučivanja zvanja [izv. un discernimento vocazionale] ${ }^{16}$. Riječ je dakle o pozivu - odzivu, zvanju - obligaciji pred Bogom, a ne samo pred sobom i bližnjim.

Bračni savez između muškarca i žene temelji se na savezu Krista i Crkve (usp. Ef 5, 22-27); znak (metafora) je i sakrament ljubavi između Krista i čovječanstva ${ }^{17}$. Ta metafora nije lako shvatljiva ljudima danas. Papa objašnjava da je brak sakramentalno uprisutnjenje Božje ljubavi, onoga što se zbilo na Isusovu križu. No ne propušta kazati da treba sačuvati svijest o našoj manjkavosti jer je riječ o $\gg$ pozivu na življenje bračne ljubavi kao nesavršenoga znaka između Krista i Crkve $\ll^{18}$. Zato se i razlučivanje zvanja odnosi na ozbiljno i suzdržano korištenje velikim riječima, jer nijedna metafora nije savršena ni potpuna. I u sljedećem broju o sakramentu ženidbe naglasit će se uzajamno potpuno darivanje, vjernost i otvorenost životu supružnika, kako je to Krist učinio za Crkvu, ali će se ponovno istaknuti nedostatnost naše ljubavi, nesavršenost naših usporedbi i nužnost oslonca na Boga: »Premda je 'analogija između para muž-žena i Krist-Crkva' 'nesavršena analogija', ona poziva da molimo Gospodina da izlije svoju ljubav na svaki bračni par ${ }^{19}$.

Još izričitiji zahtjev razlučivanja u traženju od supružnika da se ugledaju u Krista i »reproduciraju « onu ljubav koju on ima prema Crkvi iskazan je u pozivu pastirima da se na nesavršene ljude ne stavlja pretežak teret. Pobudnica traži da se bude pažljiv, ne samo prema ljudskim slabostima, krhkostima nego i čovjekovim limitiranostima. Ljudske se granice ne smiju »maltretirati «, kako to rado čine svećenici vjernicima, konkretno, supružnicima: »Ne smijemo, međutim, miješati različite razine: ne smije se na dvije ograničene osobe svaljivati golemo breme da moraju savršeno reproducirati jedinstvo koje postoji između Krista i njegove Crkve, jer brak kao znak uključuje «, ovdje se citira Familiaris consortio, »'dinamičan proces koji postupno vodi naprijed, zahvaljujući rastućem ujedinjavanju Božjih darova’ $\ll^{20}$. Umijeće je pastoralnih radnika razlučivati i svoje i granice ljudi koje se priprema i prati do sakramenta ženidbe i dalje u obiteljskom životu.

\footnotetext{
${ }^{16}$ Isto.

${ }^{17}$ Usp. isto, br. 120.

${ }^{18}$ Isto, br. 72.

${ }^{19}$ Isto, br. 73. S. Klein govori o novoj hermeneutici znaka. Usp. S. KLEIN, Amoris laetitia und der Wandel der kirchlichen Familienvorstellungen, u: ISTI (ur.), Familienvorstellungen im Wandel. Biblische Vielfalt, geschichtliche Entwicklungen, gegenwärtige Herausforderungen, Theologische Verlag Zürich, 2018., 172-177.

${ }^{20} \mathrm{AL}$, br. 122.
} 
Pobudnica inzistira na osobnom, u našem prijevodu vlastitom razlučivanju, redovito povezanom sa savješću ${ }^{21}$. Pojedinca u razlučivanju, u donošenju životnih odluka, kao što je ulazak u brak, kao što je tragična nužnost razvoda, ne može nitko zamijeniti. Od prve do posljednje stranice toga dokumenta osjeća se stalni poziv da se postane samostalan, slobodan i zreo kršćanin te da nitko, ni biskup, ni svećenik, ni obitelj, ni zajednica vjernika, ni ikakva institucija, poglavar ili narod ne donosi odluku umjesto pojedinca, da zamijeni njegovu savjest. On tu odluku, uza sve savjete i razgovore s drugima, treba donijeti sam, promišljeno, trezveno i sabrano pred Bogom.

U VIII. poglavlju pobudnice osobno (vlastito) razlučivanje veže se uz pridjev pastoralno (br. 6, 242, 249, 293, 298, 300, 302, 304, 312) s nadopunom da se izrijekom govori i o razlučivanju pastira (br. 297, 298, 300, 302). O cilju osobno-pastoralnoga razlučivanja govori se i u vrlo važnom, ali i osporavanom br. 305. U njemu se iznova očituje koliko je papi Franji stalo da nauk pobudnice utemelji u evanđelju i koncilskom nauku, posebno na nauku o savjesti (usp. GS, br. 16). U spomenutom broju stoji da se

> pastir ne može zadovoljiti samo time da primjenjuje ćudoredne zakone na one koji žive u 'neredovitim situacijama', kao da su kamenje kojim se nabacuje na živote ljudi. Tako postupaju ljudi zatvorenog srca, koji se često skrivaju čak iza crkvenih učenja, a koji 'zasjedoše na stolicu Mojsijevu i sude, pokoji put $\mathrm{s}$ visoka i površno, teške slučajeve i ranjene obitelji'. [...] Zbog uvjetovanosti i olakotnih čimbenika, moguće je da u objektivnoj situaciji grijeha - u kojoj ne postoji uopće ili dijelom subjektivna krivnja - osoba može živjeti u Božjoj milosti, može voljeti, a također može rasti u životu milosti i ljubavi, primajući u tu svrhu pomoć Crkve. ${ }^{22}$ Razlučivanje mora pomoći pronaći moguće načine odgovora Bogu i rasta usred granica. Misleći da je sve crno-bijelo, katkad zatvaramo put milosti i rasta, te obeshrabrujemo puteve posvećenja koji daju slavu Bogu $\ll^{23}$.

${ }^{21}$ Usp. isto, br. 37, 297, 298 i 300. »Nailazimo na teškoće u predstavljanju braka više kao dinamičnog puta osobnoga razvoja i ispunjenja no kao teret koji treba podnositi cijeli život. Mučimo se također dati prostor savjesti vjernikâ, koji usred svojih ograničenosti vrlo često odgovaraju što je bolje moguće na evanđelje, te su sposobni ostvariti svoje vlastito razlučivanje u složenim okolnostima. Pozvani smo odgajati savjesti, a ne težiti tome da ih zamijenimo (AL, br. 37).

${ }^{22}$ Ovdje se navodi bilješka 351, također mnogo osporavana: »U određenim slučajevima to može uključivati pomoć sakramenata. Zbog toga 'svećenike podsjećam da ispovjedaonica nije soba za mučenje, već mjesto susreta s Gospodinovim milosrđem'« (EG, br. 44) - naprijed također citiran br. 44.

${ }^{23}$ AL, br. 305. 
I navodi već spominjani broj EG 44 da Bogu može biti važniji mali korak usred velikih ljudskih ograničenja od, izvana gledano, ispravnoga života onoga koji u svome životu ne nailazi na veće poteškoće.

Osobno razlučivanje ovisi i o društvenom i crkvenom kontekstu, o kulturi, narodu, jeziku. Razlučivanje je kao i vjera povezano s inkulturacijom evanđelja. Papi je stalo do jedinstva u razlikama, ali i da svako opće načelo treba biti inkulturirano u svakoj mjesnoj $\mathrm{Crkvi}^{24}$. Citirajući koncilski misijski dekret Ad gentes, pobudnica napominje važnost razlučivanja (u nas prevedeno s razabiranje) sjemenki Riječi u drugim kulturama, naravnim ženidbama i ženidbenim modelima drugih vjerskih predaja: »Možemo reći da 'svaka osoba koja želi u ovom svijetu zasnovati obitelj koja uči djecu da se raduju svakom djelu kojim se želi pobijediti zlo - obitelj koja pokazuje da je Duh živ i da djeluje - naići će na naše poštovanje i zahvalnost, bez obzira na to kojem narodu, vjeri ili regiji pripadala! $\ll^{25}$

Važno razlučivanje (ovdje rasudivanje) treba se ostvarivati i u području tjelesnosti, spolnosti. Pobudnica citira Ivana Pavla II. da je $\gg$ ljudsko biće 'pozvano na punu i zrelu spontanost u svojim odnosima', koja 'je plod rasuđivanja o nagonima vlastitoga srca koji postupno sazrijeva' ${ }^{26}$.

Kod govora da pastiri trebaju ohrabrivati obitelji na rast u vjeri, na molitvu, da trebaju pohoditi ljude u njihovim domovima te osnažiti obiteljski pastoral kroz čitanje Svetoga pisma u crkvenoj zajednici, riječ je također o razlučivanju: »Božja riječ nije samo radosna vijest za osobni život pojedinca nego i kriterij za prosuđivanje [giudizio] i svjetlo za raspoznavanje [discernimento] različitih izazova, s kojima se suočavaju supruzi i njihove obitelji $\ll^{27}$. Božja riječ više je od pukoga sredstva kojim razlučujemo svoje situacije, razabiremo i prosuđujemo okolnosti. Božja riječ svjetlo je našemu životnomu putu, osobnomu i obiteljskomu.

\subsection{RAZLIČITA RAZLUČIVANJA - ISTI IDEAL}

Iako se razlučivanje u pobudnici Amoris laetitia najviše tiče pastira, pa se najviše i govori o pastoralnom razlučivanju, pri tome valja ponavljati da se tim pozivom pastirima od njih traži da i sami budu, a i da vjernicima pomognu da budu što osobniji

\footnotetext{
${ }^{24}$ Usp. isto, br. 3.

${ }^{25}$ Isto, br. 77.

${ }^{26}$ Isto, br. 151. Usp. E. SCHOCKENHOFF, Traditionsbruch oder notwendige Weiterbildung?, Zwei Lesarten des Nachsynodalen Schreibens Amoris laetitia, u: G. AUGUSTIN, I. PROFT (ur.), Zum Gelingen von Ehe und Familie. Ermutigung aus Amoris laetitia (Für Walter Kardinal Kasper), Freiburg-Basel-Wien, 2018., 292s.
}

${ }^{27} \mathrm{AL}$, br. 227. 
u svom razlučivanju. Nitko nikoga ne može zamijeniti u tom odgovornom procesu i činu vjere. Smatramo da je razlučivanje u našoj kulturi brzine i površnosti nasušna krjepost. Ono podrazumijeva suptilnost, a ne grubost, izoštrenost duha, a ne ravnodušnost, istančanost pogleda i sluha, ne grubijanstvo. Stoga ćemo s teologom A. Donatom još jednom prijeći pobudnicu i pogledati kojim se pridjevima i u kojem kontekstu pobudnica koristi uz pojam razlučivanja. ${ }^{28}$ Pritom imamo u vidu da je svaki brak, svaka obitelj svijet za sebe, pogotovo kad se nađu u krizi. Upravo nam i to razlučivanje razlučivanja treba pomoći da budemo što pozorniji u obiteljskom pastoralu.

Pomno (attento) razlučivanje i praćenje ispunjeno poštovanjem zahtijevaju situacije onih razvedenih koji su stupili u novu vezu, čime nipošto nisu izopćeni ${ }^{29}$. Te se osobe trebaju osjetiti dijelom Crkve i briga o njima, naglašava pobudnica, $\gg$ ne slabi vjeru zajednice i njezino svjedočenje o nerazrješivosti ženidbe, nego štoviše, ona upravo po toj brizi izražava svoju ljubav $\ll^{30}$.

O prikladnom (adeguato) razlučivanju, u nas prevedeno odgovarajućem, govori se pri lučenju vrlo različitih situacija rastavljenih osoba. Izričito se traži da različite situacije $\gg$ ne treba svrstati u strogo zadane okvire ili pretjerano krute klasifikacije, ne ostavljajući prostora za odgovarajuće osobno i pastoralno razlučivanje ${ }^{31}$. Vrlo su različite okolnosti u kojima se netko od supružnika može naći (primjerice: u drugoj vezi s djecom, u vjernosti i sa svom sviješću o neredovitosti vlastite situacije; ili u situaciji kada zbog odgoja djece muž i žena ne mogu ispuniti obvezu rastave; ili nakon što je pojedinac uložio velike napore da spasi brak, sve je bilo bezuspješno i biva napušten; ili su neki sklopili drugu vezu zbog odgoja djece, a imaju subjektivnu sigurnost da njihov prijašnji brak, nepopravljivo razoren, nikada nije bio valjan).

$\gg$ Nešto je sasvim drugo «, naglašava dalje pobudnica, »nova veza proizišla iz nedavnog razvoda, uz sve patnje i konfuzije koje to za sobom povlači za djecu i cijele obitelji, ili ako je riječ o nekom tko je uporno propuštao ispunjavati obiteljske obveze. Mora biti jasno da to nije ideal koji evanđelje predlaže za brak i obitelj. Sinodski su oci rekli da pastiri moraju uvijek 'lučiti na prikladan način situacije' [kurziv naš] s pogledom koji zna razlikovati situaciju jednu od druge. Znamo da ne postoje 'jednostavni recepti' $\ll^{32}$.

\footnotetext{
${ }^{28}$ Usp. A. DONATO, Il discernimento pastorale misericordioso, 70-71.

${ }^{29}$ Usp. AL, br. 243.

${ }^{30}$ Isto.

${ }^{31}$ Isto, br. 298.

${ }^{32}$ Isto.
} 
Odgovorno (responsabile) razlučivanje tematizirano je u br. 300-303 VIII. poglavlja pobudnice. Tu je riječ o stupnju odgovornosti koji se razlikuje od slučaja do slučaja. »Prezbiteri imaju zadaću savjetovati osobe u odgoju za razabiranje $\ll^{33}$, posebno rastavljene, kako bi oni sami bili u stanju prepoznavati Božju volju. Riječ je o

»putu praćenja i razlučivanja koji navodi te vjernike da osvijeste svoje stanje pred Bogom. Razgovor sa svećenikom in foro interno pomaže im donijeti ispravan sud o zaprjekama punijem sudjelovanju u životu Crkve, kao i sud o koracima koji im mogu pogodovati i pospješiti njegovo ostvarenje. Budući da u zakonu kao takvom nema postupnosti (usp. FC 34) ${ }^{34}$, to razabiranje nikad ne smije djelovati mimo zahtjeva evanđeoske istine $\mathrm{i}$ milosrđa što ih Crkva izlaže $\ll{ }^{35}$.

Iako pobudnica inzistira na uvažavanju olakotnih okolnosti i postupnosti primjene propisa, ona traži da se budno i posve odgovorno pazi, odnosno da se razluču$j u$ slučajevi ${ }^{36}$ kako se ne bi ostavio dojam da pojedini svećenik začas može srediti bračne probleme i iznimke ili da netko može $\gg$ ishoditi sakramentalne povlastice $u$ zamjenu za usluge $\ll{ }^{37}$. Pobudnica nastavlja: $\gg$ Kad se odgovorna i diskretna osoba, koja ne teži stavljati svoje vlastite želje iznad općeg dobra Crkve, nađe s pastirom koji zna prepoznati ozbiljnost pitanja koji mu je podastrt, izbjegava se opasnost da određeno razlučivanje dovede ljude do toga da misle kako Crkva podržava dvostruki moral $\ll^{38}$. Tim se poziva na odgovornije pristupanje i realizaciju bračnih parnica i procesa za proglašenje ništavosti braka - bez privilegija i povlastica za neke, a za druge stroga primjena propisa.

Posebno (speciale) razlučivanje odnosi se na određene $\gg$ neredovite $\ll$ situacije, pri čemu se - pobudnica nalaže - ne smije ni pomisliti $\gg$ da se zahtjevi evanđelja na bilo koji način žele umanjiti ${ }^{39}$. Ublažavajući uvjeti i okolnosti znače da oni $\mathrm{u} \gg$ nere-

${ }^{33}$ Isto, br. 300.

${ }^{34}$ Usp. D. BOGNER, Angedeuteter Wandel. Die Ambivalenz von $\gg$ Gradualität in Amoris laetitia «, u: S. GOERTZ, C. WITTING (ur.), Amoris laetitia - Wendepunkt für die Moraltheolgie, Freiburg im Breisgau, 2016., 201-223.

${ }^{35}$ AL, br. 300.

36 »Različitost i složenost situacija ima za posljedicu diferencirano vrjednovanje stupnja odgovornosti, a također i učinaka normi (... ). U konačnici [papa] ne čini ništa drugo, nego potvrđuje klasičnu pozornost katoličkoga morala na razlikovanje grijeha i grješnika « (M. OMETTO, Divorziati che vivono una nuova unione nella Chiesa cattolica, 257.). Usp. također S. ERNST, »Irreguläre Situationen « und persönliche Schuld in Amoris laetitia. Ein Bruch mit der Lehrtradition?, u: S. GOERTZ, C. WITTING (ur.), Amoris laetitia - Wendepunkt für die Moraltheolgie, 136-159.

${ }^{37}$ AL, br. 300.

${ }^{38}$ Isto.

${ }^{39}$ Isto, br. 301. 
dovitim « situacijama nisu uvijek u smrtnom grijehu niti su lišeni posvetne milosti, kao i da nije riječ o pukom nepoznavanju propisa. ${ }^{40}$ Dokument se poziva na nauk Crkve (posebno na nauk Tome Akvinskoga) da pojedine okolnosti mogu utjecati na mogućnost smanjenja ili ograničenja sposobnosti razumijevanja i odlučivanja. ${ }^{41}$

Razlučivanje je, već smo prije napomenuli, uvijek vezano za savjest. Savjest pak nije statična zbilja, nego se oblikuje, izgrađuje, odgaja. Odatle, prema pobudnici, razlučivanje nije samo odgovorno i ozbiljno, nego je dinamično i uvijek otvoreno za nove situacije, za nova učenja i odlučivanja, za uvijek veće približavanje idealu braka i obitelji. U tom se smislu kaže:

»Naravno treba svim silama poticati razvoj prosvijetljene savjesti, oblikovane i vođene od odgovornog [responsabile] i ozbiljnog [serio] razlučivanja nekog pastira, te predlagati sve veće povjerenje u Božju milost. Ali ista ta savjest može prepoznati ne samo da određena situacija objektivno govoreći ne odgovara zahtjevima evanđelja nego također može prepoznati iskreno i pošteno ono što je trenutačno najvelikodušniji odgovor koji mogu dati Bogu i uvidjeti s određenom moralnom sigurnosti da je upravo to ono što sâm Bog traži usred konkretne složenosti nečijih ograničenosti, premda to još nije potpuno opredmećen [objektivan] ideal. U svakom slučaju, podsjećamo da je to razlučivanje dinamično [dinamico] i mora ostati uvijek otvoreno [aperto] za nove etape rasta i nove odluke koje omogućuju potpunije ostvarenje ideala $\ll{ }^{42}$.

Pozivajući se ponovno na Tomu Akvinskoga da norma (načelo, regula) i »opći propisi « ne mogu obuhvatiti sve okolnosti niti se mogu apsolutno primijeniti na sve pojedine situacije, Amoris laetitia koristi se oštrim moralnim sudom u slučaju da netko svodi svoj pastoralni rad jedino na to da promatra odgovaraju li postupci pojedine osobe općem zakonu ili propisu. Takvo ponašanje pobudnica naziva pridjevom meschino - što je više od našega prijevoda uskogrudo jer označava i moralnu zloću i kukavnost onoga tko tako postupa, »jer to nije dovoljno da se razabere i

\footnotetext{
40 »Pojedinac može dobro poznavati propis, ali ima velike teškoće u razumijevanju 'vrednota sadržanih u ćudorednom propisu' ili se može nalaziti u konkretnim prilikama koje mu ne dopuštaju djelovati drukčije i donositi druge odluke, a da ne učini novi grijeh $\ll(A L, b r .301)$.

${ }^{41}$ Usp. isto. »Već je sveti Toma Akvinski shvatio da netko može imati milosti i ljubavi, a ipak biti nesposoban dobro vršiti kreposti; drugim riječima, iako netko može posjedovati sve ulivene ćudoredne kreposti, on ne očituje jasno postojanje bilo koje od njih, jer ima teškoća s njihovim izvanjskim vršenjem: 'Za neke se svece kaže da nisu posjedovali određene kreposti, jer su imali teškoća u njihovu činjenju, ( ... ) ipak bili su urešeni svim krepostima’ « (AL, br. 301).

${ }^{42}$ Isto, br. 303.
} 
zajamči potpuna vjernost Bogu u konkretnom životu ljudskoga bića $\ll^{43}$. S druge strane pobudnica ne upada ni u relativizam vrjednota ni u subjektivizam kazuistike niti osobno iskustvo i praktično (pratico) razlučivanje može postati općevažećom normom za sve: »Istodobno, treba reći da, upravo zato, ono što je dio praktičnog razlučivanja u posebnim okolnostima ne može biti uzdignuto na razinu propisa. To ne samo da bi dovelo do nepodnošljive kazuistike nego i do ugrožavanja samih vrednota koje se mora posebno brižno čuvati $\ll^{44}$.

Pastoralno milosrde (naslov je jednoga dijela VIII. poglavlja), koje se najviše traži od biskupa i svećenika u razlučivanju pojedinih okolnosti, poglavito $\gg$ neredovitih $\ll$ situacija, ne znači nikakav mlak vjernički stav ili relativizaciju ideala nerazrješivosti braka i obiteljske zajednice ${ }^{45}$. Milosrđe je ključ razumijevanja toga dokumenta, kao i cjelokupnoga pontifikata pape Franje, kriterij tko je istinski kršćanin i što je istinski pastoral Crkve. Ponavljaju se riječi bule Misericordiae vultus (br. 10):

$\gg$ milosrđe nije samo djelo Oca, već postaje kriterij za utvrđivanje tko su njegova prava djeca. (...) 'milosrde je sam temelj [architrave - nosiva greda] na kojem počiva život Crkve. Cjelokupno njezino pastoralno djelovanje moralo bi biti obavijeno nježnošću koju pokazuje prema vjernicima; ništa u njezinu naviještanju i njezinu svjedočenju svijetu ne bi smjelo biti lišeno milosrđa.' $\ll 6$

Čini se da u kršćana, pogotovo u teolozima, svećenicima, biskupima, ima više straha od Boga i osjetljivosti za pravdu nego za milosrđe, pa smatraju da se s pravdom ne može pretjerati, a s milosrđem može, i to uvijek. Ovaj papa naglašava suprotno. Milosrđe ne isključuje pravdu i istinu niti je razvodnjavanje evanđelja, nego je » milosrđe punina pravde i najjasnije očitovanje Božje istine «, pa je i »svako teološko shvaćanje $\ll$, pobudnica se izravno referira na moralnu teologiju, »koje u konačnici dovodi u sumnju svemoćnost samoga Boga, a osobito njegovo milosrde, potpuno neprimjereno $\ll{ }^{47}$. Kriterij bezuvjetnoga Božjega milosrđa ${ }^{48} u$ pastoralu

\footnotetext{
${ }^{43}$ Isto, br. 304.

${ }^{44}$ Isto.

${ }^{45}$ Usp. isto, br. 307.

${ }^{46}$ Isto, br. 310. I nastavlja s citatom iz EG, br. 47: »Istina je da se katkad 'ponašamo poput kontrolora milosti, a ne kao njezini omogućitelji. No Crkva nije carinarnica, ona je očev dom, gdje ima mjesta za svakoga s njegovim tegobnim životom. «

${ }^{47}$ AL, br. 311.

${ }^{48}$ Bilješka 364 odnosi se na tvrdnju: »Pokatkad nam je vrlo teško ostaviti mjesta u pastoralu za bezuvjetnu Božju ljubav«, a glasi: »Možda iz neke obzirnosti, koja se krije iza velike želje za vjernošću istini, neki svećenici traže od pokornikâ odluku o kajanju u kojoj nema tračka sumnje, što ima za posljedicu da milosrđe biva zaklonjeno traženjem navodno čiste pravde. Zato je korisno podsjetiti na učenje svetog Ivana Pavla II. koji je rekao da predvidivost nekog pada 'ne prejudicira autentičnost odluke.«
} 
>pruža okvir i ozračje koje nam pomaže izbjegavati hladni birokratski moral u pristupanju osjetljivim temama i postavlja nas u kontekst pastoralnog razlučivanja ispunjena milosrdnom ljubavlju, koja je uvijek sprema razumjeti, oprostiti, pratiti, nadati se i iznad svega integrirati. To je logika koja bi trebala prevagnuti u Crkvi i voditi nas do toga da 'otvorimo srce onima koji žive u najudaljenijim egzistencijalnim periferijama' [MV $15] \ll{ }^{49}$.

U razlučivanju okolnosti i stupnja odgovornosti nije riječ o situacijskoj etici koja bi dovela u pitanje smislenost postojanja zakona i normi. ${ }^{50}$ No nije riječ ni o pukoj, bezdušnoj primjeni normi, nego o razboritom uvažavanju okolnosti, uvažavanju čovjekove povijesnosti i usuglašavanju s propisom. Riječ je o uvažavanju stupnjevitosti u čovjekovu rastu (ne o stupnjevitosti zakona, propisa ili ideala), dakle o stupnjevitosti odgovornosti i djelovanju po savjesti, o procesu u pastoralu i o središnjosti savjesti, naposljetku o autonomiji u vjeri i praksi vjere, kao i o vlastitoj odluci, i to odluci za ljubav. A od ljubavi nema ničega zahtjevnijega.

Savjest pojedinca, traži Amoris laetitia, »mora biti bolje ugrađena u praksu Crkve u određenim situacijama koje objektivno govoreći ne odjelotvoruju naše shvaćanje ženidbe $\ll^{51}$. Svjestan je Papa da je teško odgojiti prosvijetljenu, zrelu savjest te da taj proces traje čitava života jer nitko nikada nije završen, cjelovit čovjek. Svjestan je također, i iznova citira svoj programski spis Evangelii gaudium, da neki pastiri, ali i vjernici, vole stroži pastoral i pravnu nepopustljivost ${ }^{52}$, da su neki jednostavno skloniji neslobodi, da neki vole vojnički ustroj i slijepu poslušnost u Crkvi. Pobudnicom se Papa ne želi zaustavljati na ljudskim pravnim uskoćama i moralnim zloćama, nego sve poziva na evanđelje milosrđa po kojem se traži da Kristova zajednica - Crkva - bude majka, suosjećajna i solidarna sa slabima, da se čuva prejakih i završnih osuda, kao i udobnih skloništa daleko od drame ljudskih odnosa i obiteljskih sudbina. ${ }^{53}$

\footnotetext{
${ }^{49}$ AL, br. 312.

${ }^{50}$ Neki autori govore o etici razlučivanja. »Polazeći od AL, otkriva se mogućnost Crkve da čini diferencirano vrjednovanje krivnje osobe, a da se ne niječe ili stavlja u sumnju povreda objektivne norme $\ll$ (usp. M. OMETTO, Divorziati che vivono una nuova unione nella Chiesa cattolica, 260.).

${ }^{51}$ AL, br. 303.

${ }^{52}$ Usp. isto, br. 308.

${ }^{53}$ Usp. isto. »Razumijem one koji više vole strožu pastoralnu skrb, koja ne ostavlja prostora bilo kakvoj pomutnji. Ali iskreno vjerujem da Isus želi Crkvu osjetljivu na dobro koje Duh Sveti sije usred ljudske slabosti, majku koja, dok jasno izlaže svoje objektivno učenje, 'čini ono dobro koje se da učiniti, čak i ako se time izlaže opasnosti da cipele zaprlja blatom s ulice' [EG 45]. Crkveni pastiri koji predlažu vjernicima puni ideal evanđelja i crkvenog učenja moraju im pomoći usvojiti stav suosjećanja prema slabim osobama i da se klone njihova proganjanja ili previše oštrih ili brzopletih sudova. Sámo
} 
Franjo Asiški, po kojem je sadašnji papa izabrao ime (prvo u povijesti papinstva!), nije dopuštao svojoj braći nikakva velika tumačenja i pojašnjavanja evanđelja (sine glossa). Uklanjao se od pravnih tumačenja i juridiziranja evanđelja i svoga pokorničkoga života po evanđelju. Zato za svoje bratstvo nije prihvatio nikakvo već postojeće redovničko pravilo (ni Benediktovo, ni Augustinovo, ni cistercitsko, za razliku od drugih, pa i za razliku od njegova suvremenika sv. Dominika), nego se dugo mučio u sastavljanju pravila (tri pravila), nastojeći pravne propise svesti na najmanju mjeru, samo kako bi zadržao ideal evanđelja. »Pravilo manje braće jest opsluživanje evanđelja «, stoji na početku Franjina pravnoga spisa. Imajući to u vidu, mislimo da nekima može izgledati da se u pobudnici pape Franje prenaglašava sučeljavanje prava i pastorala, propisa i milosrđa. A. Spadaro o tom problemu kaže:

»Pastoralna briga ne treba biti tumačena i suprotstavljana pravu. Naprotiv: ljubav za istinom točka je temeljnoga susreta između prava i pastorala; istina nije apstraktna, nego se integrira u ljudski i kršćanski itinerar svakoga vjernika. Takav pastoral nije ni puka praktična aplikacija teologije. Nije riječ o prilagođavanju pastorala doktrini, nego neoduzimanju doktrini izvornoga i konstitutivnoga pastoralnoga pečata. $\ll^{54}$

Nasljedovanje je evanđelja prije svakoga prava i propisa.

\section{Integriranje u zajednicu}

Put i djelovanje Crkve, prema pobudnici Amoris laetitia, nikada ne bi smjeli biti (vječna) osuda i izopćenje iz Crkve, nego neumorno iskazivanje Božjega milosrđa svima ${ }^{55}$, suosjećajna pratnja, pomaganje i aktivna solidarnost $\mathrm{s}$ onima koji su u nevoljama. Milosrđe je nezasluženo, bezuvjetno i besplatno ${ }^{56}$. Sve to ima za cilj integraciju svih u crkvenu zajednicu bez obzira na to u kakvoj se situaciji oni našli. Premda se računa kao treći korak u pastoralnoj metodologiji, integracija u crkvenu, Kristovu zajednicu treba biti stalna želja i nastojanje pastoralnih radnika, i dok se prati mlade zaručnike i mlade obitelji, a posebno one u krizama odnosa.

Pobudnica u tom smislu izrijekom kaže, a čini se da u tekst zahvaća sam papa Franjo jer opet nailazimo na riječi u ja formi:

evanđelje od nas traži da ne sudimo ili osuđujemo (usp. Mt 7,1, Lk 6,37). Isus ‘čeka da prestanemo tražiti ona osobna i zajednička skloništa koja nam omogućuju da se držimo podalje od vrtloga ljudskih drama i da umjesto toga uistinu prihvatimo susresti se s konkretnom stvarnošću drugih ljudi i upoznamo snagu njegove nježnosti. Kada to činimo, naš život postaje čudesno složena pustolovina'« [EG 270] (AL, br. 308). O Crkvi kao majci koja ne smije osuditi ni napustiti, ni bacati kamenje osude na svoju djecu, nego je pozvana donositi Božje milosrđe usp. također AL, br. 49.

${ }^{54}$ A. SPADARO, Introduzione: Amoris laetitia, 28.

${ }^{55}$ Usp. AL, br. 296.

${ }^{56}$ Usp. isto, br. 297. 
»Riječ je o tome da se sve uklopi, svakome treba pomoći da nađe vlastiti način sudjelovanja u crkvenoj zajednici i tako iskusi da mu je ukazano 'nezasluženo, bezuvjetno i besplatno' milosrđe. Nikoga se ne smije zauvijek osuditi, jer to nije logika evanđelja! Tu ne mislim samo na rastavljene i ponovno vjenčane, nego na sve, bez obzira na stanje u kojem se nalazili. Naravno, ako se netko razmeće objektivnim grijehom kao da je dio kršćanskog ideala, ili želi nametnuti nešto drugo od onoga što Crkva uči, ne može ni na koji način tražiti da predaje vjeronauk ili propovijeda: u tom slučaju postoji nešto što ga odvaja od zajednice (usp. Mt 18,17). Takav treba iznova slušati evanđelje i njegov poziv na obraćenje. Ali čak i za tu osobu može postojati neki način sudjelovanja u životu zajednice: u socijalnim službama, molitvenim susretima ili na drugi način koji sam pojedinac predloži, a o čemu svoj sud treba donijeti župnik « ${ }^{57}$.

Za integriranje u zajednicu traži se dakle da ne dođe do sablazni, ali da nikada ne bude ponašanje starijega sina koji ne dopušta mogućnost obraćenja svoga brata, svoga bližnjega. ${ }^{58}$ Čak i onim > osobama koje su sklopile građanski brak, te rastavljenim i ponovno oženjenim odnosno osobama koje žive u izvanbračnoj zajednici, zadaća je Crkve objaviti im Božju pedagogiju milosti u njihovom životu i pomagati im postići puninu Božjeg nauma $(. ..) \ll^{59}$. Što je u takvim slučajevima konkretno Božja pedagogija milosti koju Crkva treba pokazati i omogućuje li se konkretna promjena prihvaćanja u zajednicu, konkretno davanje nekih službi takvim članovima, koje su do sada bile nedopuštene, uopće nije točno kazano.

Ipak, i taj općenito izrečeni zahtjev traži od Crkve, ponajprije crkvenih pastira, da ne ostavljaju ljude same, da ih ne isključuju iz crkvene zajednice, nego da im budu blizu, da im pomognu, da osobe u grješnim ili $u$ »neredovitim « (nesavršenim, nepotpunim i krhkim) situacijama imaju siguran oslonac, utjehu i pratnju u vjeri te da »razaberu koji se od raznih oblika isključenja, koji su sad na snazi u liturgijskom, pastoralnom, obrazovnom i institucionalnom okviru, mogu prevladati $\ll^{60}$. Pastiri su također pozvani da, ne umanjujući visoki ideal braka i obitelji, u svjetlu Božje ri-

\footnotetext{
${ }^{57}$ Isto.

${ }^{58}$ Usp. L. MARTÍNEZ SISTACH, Come applicare l'Amoris laetitia, 77.

${ }^{59}$ AL, br. 297.

${ }^{60} \mathrm{AL}$, br. 299. Prema važećim dokumentima, posebno Kongregacije za nauk vjere iz razdoblja dok je njome upravljao kardinal J. Ratzinger, rastavljeni su isključeni iz ovih službi u Crkvi: akolita i čitača, službe izvanrednoga djelitelja pričesti, kuma na krštenju i potvrdi, katehete, nastavnika u katoličkim školama, nastavnika vjeronauka u javnim školama, člana biskupijskoga ili župnoga pastoralnoga vijeća (usp. M. OMETTO, Divorziati che vivono una nuova unione nella Chiesa cattolica, 185.).
} 
ječi, u svjetlu evanđelja i Isusove prakse, razlučuju pojedine slučajeve, kao i da s delikatnošću Dobroga Pastira pristupaju svakom pojedinom čovjeku, braku i obitelji.

Integracija u crkvenu zajednicu ne događa se po izvanjskom sviđanju niti iz kakvih sporednih razloga, nego radi spasenja bližnjih, i to tako da u svemu treba biti tražena Božja volja ${ }^{61}$. Uvijek vrijedi imati na umu da nijedno ljudsko zajedništvo, pa tako ni obitelj nije savršena niti konfekcionirana za sva vremena, nego zahtijeva stupnjeviti razvoj vlastitih sposobnosti ljubavi. ${ }^{62}$ Kao što u Božjoj pedagogiji postoji stupnjevitost i Bog je strpljiv s čovjekom kako bi čovjek postao što zreliji u svojoj vjeri, tako je i sa zrelošću ljudi i ljudskih zajednica. I one se mogu razvijati prema sve boljim odnosima, a mogu tonuti u paklena stanja zlostavljanja i nasilja, sukoba i razvoda. Mogli bismo kazati da u podnožju pobudnice Amoris laetitia stoji istina vjere da Bog čitava života odgaja ljude pojedinačno i u zajednici, da Isus Krist nije došao spasiti samo čovjeka pojedinca, nego ozdraviti i osnažiti njegove odnose polazeći od onih s bližnjima pa sve do odnosa sa susjedima i, nipošto na zadnjem mjestu, do odnosa s neprijateljima.

Pobudnica traži od pastoralnih radnika stalno i istančano razlučivanje okolnosti, poštovanje psihološko-religioznoga, duhovnoga profila pojedinih vjernika, njihovih granica i mogućnosti te prihvaćanje činjenice da se sve događa u vremenu, dakle da je sve u procesu mogućega sazrijevanja ${ }^{63}$. Zakon postupnosti i rasta osobito se naglašava u obiteljskoj duhovnosti, posljednjem poglavlju pobudnice (Bračna i obiteljska duhovnost), gdje se od svakoga bračnoga druga i člana obitelji traži da raste preko svojih ograničenosti i granica, ali tako da se nekim visokim zahtjevima ne stvara od ljudi ozlojeđene i depresivne osobe jer osjećaju da ne mogu učiniti ono što se od njih traži. Nije naime rijetkost da postavljanjem previsokih ciljeva bližnjima, supružnici jedno drugom ili roditelji djeci, netko liječi vlastite komplekse i frustracije ili netko od bračnih drugova drugoga maltretira krivnjama i stalnim zahtjevima da čini ono što nije u mogućnosti jer jednostavno nije u stanju prijeći svoje granice. Ima supružnika ili roditelja koji svomu najbližem ili djeci ne dopuštaju ne samo uspjeh nego da bude lijep ili da se igra. Ima onih koji nisu prihvatili Božju milost postojanja i bližnjega kao dar, pa bi svojim bližnjima, da mogu, oduzeli i osmijeh i radost postojanja.

Zakon postupnosti zapravo počiva na biblijskom i uopće vjerničkom iskustvu Božjega postupnoga odgajanja ljudi, obitelji i naroda. Pa kad se govori o nužnosti

\footnotetext{
${ }^{61}$ Usp. AL, br. 300.

$62 \gg$ Kao što smo više puta podsjetili u ovoj pobudnici, nijedna obitelj nije potpuno oblikovana stvarnost ili gotov proizvod, nego stalno treba rasti i sazrijevati u sposobnosti da ljubi« (isto, br. 325).

${ }^{63}$ Usp. isto, br. 303-304.
} 
nadilaženja svojih granica, na rastu iznad sebe, o samonadilaženju, to znači tako izgrađivati i sebe i svoju obiteljsku zajednicu da se osjeti da u njoj Bog prebiva, da se postupa u skladu s Božjom stupnjevitom pedagogijom koja uvažava dobne i druge razlike svoje djece ${ }^{64}$. I u većim župnim i u manjim obiteljskim zajednicama, naglašava Amoris laetitia, iznimno je evanđeoski promatrati »naše najmilije Božjim očima i vidjeti Krista u njima ${ }^{65}$. Evanđeoskim se razlučivanjem poštuje dostojanstvo drugoga, izbjegava ona skliska napast da se na bližnjega tako naviknemo pa ga pretvaramo u svoga poslušnika, predmet svojih ljutnji, frustracija i nesreća. A strpljivom ljubavlju koja uvažava vrijeme i postupnost njeguje se pozornost i čuva nježnost da se ne otvrdne u prohtjevima i oporoj svojeglavosti, kao i da se bez milosti ne donese definitivna osuda.

Integrirani pojedinac u zajednici pokazuje se u činjenici da bez milosti ne prosuđuje bližnje, da se lažno ne sablažnjava nad njihovim slabostima i grijesima i pritom ništa ne čini da bližnjem pomogne; da ne tovari terete bližnjima koje sam ne će nositi te da, povrh svega, nije teret svojim ukućanima i svojoj župnoj zajednici, nego blagoslov. Usto integrirani pojedinac u obitelji i župnoj zajednici jest onaj koji uvijek raste prema višem, sve je delikatniji u prepoznavanju različitosti situacija svojih bližnjih i njihovih osobnosti te u skladu s njima pokazuje svoje razumijevanje i milosrđe te onu uvijek tako nasušnu krjepost - socijalnu ljubav koja se ponajviše očituje u gostoljubivosti. ${ }^{66}$

I pojedinac i njegova zajednica, obiteljska i prijateljska, župna i šire crkvena, narodna i društvena, i čovječanstvo kao Božja obitelj, prema pobudnici Amoris laetitia, povijesne su zajednice, putujuće - hodočasničke, da se izrazimo biblijski i koncilski. To podrazumijeva da u razmišljanju i hodu prema punini, završava pobudnica,

>prestanemo tražiti od naših međuljudskih odnosa savršenstvo, čistoću namjerâ i dosljednost koju ćemo moći susresti samo u Kraljevstvu koje dolazi. To nas također čuva od toga da strogo sudimo one koji žive u vrlo krhkim situacijama. Svi smo pozvani nastaviti težiti nečemu višem od sebe i naših granica i svaka obitelj mora osjetiti taj stalni poticaj. ${ }^{67}$

\footnotetext{
${ }^{64}$ Usp. isto, br. 314.

${ }^{65}$ Isto, br. 323.

${ }^{66}$ Usp. isto, br. 324. »Kad obitelj prihvaća druge i izlazi im ususret, osobito siromašnima i napuštenima, ona 'postaje simbol, svjedočanstvo, udioništvo u majčinstvu Crkve'. Socijalna ljubav, taj odraz Trojstva, zapravo je ono što ujedinjuje duhovno značenje obitelji i njezino poslanje prema drugima jer uprisutnjuje kerygmu, sa svim njezinim zahtjevima vezanim uz zajednicu. Obitelj živi svoju duhovnost upravo time što je istodobno kućna Crkva i vitalna stanica za preobrazbu svijeta (isto, br. 324).

${ }^{67}$ Isto, br. 325 .
} 
Papa nastavlja i sa zanosom poziva: $\gg$ Hajdemo, obitelji; nastavimo taj hod! Ono što nam je obećano veće je nego što možemo zamisliti. Nikada ne izgubimo nadu zbog svojih ograničenja, ali ne odustajmo od toga da tražimo puninu ljubavi i zajedništva koja nam je Bog obećao $\ll{ }^{68}$.

Riječ je, dakako, o putu nesavršenih ljudi koji ne sude strogo i definitivno, nego su usmjereni k sve višoj ljubavi i zajedništvu. Teolog W. Kasper, koji je i na sinodi imao zapaženu relaciju ${ }^{69}$, ne opisuje taj put kao široki put prilagodbe situaciji, ni pojeftinjeni put u lažnom smislu liberalnoga laissez faire, ni udobni put jednostavnih priručnih recepata i propisa, nego krjeposni put ignacijanskoga magis, uvijek više i bolje. Taj »još više « opisuje visoki put kršćanske slobode u sve većoj ljubavi na koji bi nas poveo papa Franjo. ${ }^{70}$

Papa traži da put Crkve ne bude onaj koji se poduzima »od neobuzdane želje da se sve mijenja bez dovoljnoga razmišljanja ili osnovanosti « niti da s druge strane bude put kojim se misli da se sve može riješiti samo »primjenjujući norme ili izvlačeći pretjerane zaključke iz nekih teoloških razmišljanja $\ll^{71}$. Uvijek i bez iznimke put Crkve treba biti put suosjećanja, put milosrđa. Milosrđe je rodno mjesto Crkve, njezino stanje i raspoloženje, pastoral koji odslikava milosrdnoga Oca i kriterij vjere i nasljedovanja Isusa Krista.

\section{Zaključak}

Dug je bio naš put predstavljanja apostolske pobudnice Amoris laetitia - o ljubavi u obitelji, i to predstavljanja tek nekih njezinih dijelova. Izostavili smo biblijski dio, I. poglavlje. Nismo se mnogo osvrtali ni na II. poglavlje, analizu sadašnjega stanja braka i obitelji u raznim krajevima i kulturama svijeta, kao ni na izazove koji stoje pred njima. Propustili smo izvrsno IV. poglavlje, Ljubav u braku, u kojem Papa nastavlja na svoj originalan način poticati nadahnjujući i spasenjski susret današnjega čovjeka u svim njegovim obiteljskim odnosima s nenadmašnim Pavlovim himnom - evanđeljem ljubavi (1 Kor 13).

Pobudnica je i sadržajno opsežna. Tä dug je bio i put njezina nastanka i oblikovanja. Prethodile su joj ne samo dvije vrlo dinamične i otvorene biskupske sinode nego prije toga i ankete po dijecezama, pa razne sjednice i rasprave, glasine i sinteze. Rijetko je koji suvremeni crkveni događaj i papinski spis bio toliko praćen

\footnotetext{
${ }^{68}$ Isto, br. 325.

${ }^{69}$ W. KASPER, Il Vangelo della famiglia, Queriniana, Brescia, 2014.

${ }^{70}$ Usp. W. KASPER, Die Botschaft von Amoris laetitia. Ein freundlicher Disput, Freiburg-Basel-Wien, 2018., 90.

${ }^{71}$ AL, br. 2.
} 
i komentiran i unutar Crkve i uopće u javnosti kao sinode i pobudnica o braku i obitelji. Ostvarila se zamisao pape Franje da, unatoč mogućnosti raznih površnih i nedobronamjernih tumačenja (difamacija i destrukcija), sinodalni put Crkve i kolegijalnost biskupa trebaju biti otvoreni svim vjernicima i svim ljudima.

Pobudnica Amoris laetitia iznova potvrđuje svim kršćanima, posebno pastirima Katoličke Crkve, delikatnost sakramenta braka i obitelji. Naglasili smo u ovom tekstu da ona ne donosi u doktrini ništa novo, nego zahtijeva obnovljeni pastoral, iz obnovljene ekleziologije. Ni za pastoral ne rješava sve, nema tu pretenziju, ali neposustalo i s oduševljenjem iz broja u broj traži od svih da uvide važnost puta ljubavi u braku i obitelji, da tim putem hode svjesni svojih granica, kao i svoga poziva da nasljeduju onu ljubav koju Krist pokazuje prema čovjeku, čovječanstvu i svojoj zajednici, zaručnici Crkvi.

Pobudnica se - to je nit koja se provlači kroz sav spis - ne miri s pastoralnom praksom da se u Crkvi mogu oprostiti svi grijesi osim grijeha razvoda ili grijeha koji uzrokuju tzv. neredovite bračne i obiteljske situacije. Traži iznimnu pozornost $\mathrm{i}$ nježnost, ljubav i milosrđe prema svima koji su se našli u složenim situacijama, a od pastira, posebno biskupa, traži da se s više pastoralnoga sluha, istančana razlučivanja i milosrdne susretljivosti pojednostave i ubrzaju ženidbene parnice, da se pritom pozorno razmotre situacije i pastoralni zahtjevi uključivanja svih u crkvenu zajednicu. Crkva treba biti ona koja izlazi ususret ljudima, koja služi ljudima, a ne da se crkveni pastiri i služitelji svetih tajni vrte samo oko sebe, s visoke Mojsijeve stolice uživaju u svojoj birokratskoj veličini, unedogled otežu nešto što se može relativno brže riješiti te dok čuvaju svoju juridičku sliku važnosti, ne primjećuju da se i od njih i crkvene zajednice odalečuju čak i oni koji su u zajednici vjernika donedavno nalazili put $\mathrm{k}$ Bogu.

Dvije biskupske sinode o obitelji i posinodalna pobudnica Amoris laetitia iskristalizirali su važnu pastoralnu metodu u tri koraka: pratiti - razlučivati - integrirati. Ona je primjenjiva i na druga područja pastorala, ne samo na slučajeve bračnih kriza i pucanja odnosa u obiteljima. Od pastoralnih radnika posebno se traži evandeosko razlučivanje okolnosti i stupanj odgovornosti supružnika, što podrazumijeva također uključivanje vjernika, supružnika, odgoj njihove moralnosti, oblikovanje zrele savjesti, jer nitko za drugoga ne može ni vjerovati ni ljubiti.

Pobudnica traži zatim da se uvažava ljudska nesavršenost, ograničenost, postupnost rasta. Pastiri, iskusnije obitelji i sva crkvena zajednica, župa, trebaju pokazivati milosrdno gostoprimstvo svima jer za Crkvu nitko od ljudi u prekinutim odnosima, u situacijama ostavljenosti, rastavljenosti i razvoda nije izopćen niti se smije osjetiti isključenim. 
Nikada ne umanjujući ideal braka, ne podižući negativno ponašanje (rastave i razvod) na načelo djelovanja, potvrđujući nerazrješivost sakramenta braka božanskim zakonom, na pastirima je posebna odgovornost da imaju vremena i strpljenja, otvorenosti i milosrđa da susretnu takve ljude, da pomno preispitaju njihovu situaciju i da, čuvajući se sablazni u zajednici, površnih i brzih odgovora, kao i pastoralne razmetljivosti svemogućih župnika i biskupa, kao i udvaranja vjernicima, ako postoje olakotne okolnosti, omoguće pristup sakramentima. Crkva i svećenici nisu vlasnici, nego djelitelji sakramenata, posrednici Božjih spasenjskih znakova.

Nakon čitanja pobudnice dobronamjeran čitatelj zacijelo će osjetiti zanosni, ali zahtjevni govor, obnovljeni jezik o starim temama, priznanje kako je teško živjeti zajedno, u braku i obitelji, ali da je to Božja volja i izvrsni čovjekov blagoslov. U pobudnici se ne će susresti kazuistički moral ni dualizam između doktrine i pastorala niti će se zapetljati u pravno bezizlazje. Nema sumnje, pobudnica traži strpljivost u čitanju i sabranost $\mathrm{u}$ razmišljanju o njezinu sadržaju, postupnost u ostvarivanju pastoralnih smjernica. Sadržaj na prvi pogled izgleda jednostavan i jednostavno izrečen, ali kao što je to opća zakonitost, ona se pokazuje i ovdje: jednostavnost nije izraz površne neobvezatnosti, nego ishod dugoga hoda, bogata iskustva, poštenih razmišljanja i otvorenih rasprava. Tu leži i razlog da taj dokument nema toliko pravnu sistematičnost koliko moralnu i duhovno-teološku širinu i poticajnost. S pravom se i naziva pobudnicom, ohrabrenjem (exhortatio), a ne izgonjenjem grijeha i zloduha (exorcismus).

Pokazuje se također da Božje milosrđe na koje se ovaj papa toliko poziva i na koje poziva sve kršćane, pogotovo pastire Crkve, biskupe i svećenike, nije njegovo vlasništvo ni nešto što je on već dosegnuo. Riječ je o zajedničkom putu sveopće Crkve. Riječ je o Kristovu milosrđu pred kojim svi, i Papa, stojimo kao slabi i nesavršeni vjernici. Riječ je o Božjem besplatnom milosrđu koje Crkva treba posvjedočiti cijelomu svijetu, polazeći od periferija, ovdje konkretno od egzistencijalnih periferija onih koji su unesrećeni u braku, koji su ostavljeni ili koji su svojom drskošću nanijeli ili nanose nesreću svojim bližnjima. Pobudnica je svjedočanstvo da nikoga na ovoj zemlji Bog nije kaznio da bude nesretan, kao i da je svatko pozvan da usrećuje svoje bližnje. Bračni poziv jest temeljni poziv Božjega plana spasenja svakoga čovjeka.

Ovaj dugi članak u dva dijela samo je maleni doprinos velikoj raspravi; zahvala svima koji su svjedočili i svjedoče veličanstvenost bračnoga i obiteljskoga života; poziv na osobno i zajedničko čitanje i razmišljanje, razborito i milosrdno razlučivanje pastoralnih smjernica za našu osobnu i zajedničku budućnost, budućnost obitelji, župe, Crkve i čovječanstva. Vodili smo se jednostavnom mišlju koju je papa Franjo stavio na početak pobudnice Amoris laetitia: »Razmišljanje pastirâ i teologâ, ako je vjerno Crkvi, iskreno, realistično i kreativno, pomoći će nam da dostignemo veću jasnoću $\ll^{72}$.

\footnotetext{
${ }^{72}$ Isto.
} 


\title{
SOME GUIDELINES FOR THE PASTORAL CARE OF MARRIAGE AND FAMILY ACCORDING TO THE APOSTOLIC EXHORTATION AMORIS LAETITIA (II.)
}

\author{
Ivan ŠARČEVIĆ*
}

\begin{abstract}
Summary: The second part of the article $\gg$ Some Guidelines for the Pastoral Care of Marriage and Family according to the Apostolic Exhortation Amoris Laetitia $<$ focuses on the pastoral guidelines arising from the exhortation Amoris Laetitia which relate to conscientious discernment of circumstances that result in problems and divorce, and the integration of the abandoned, divorced and separated into the church community. The paper examines the importance of the concept of discernment and its stratification as well as different types of discernment. The second part, dedicated to integration into the community, seeks to present this integration in a broader context and to show the basic contours and complexity of such a process.
\end{abstract}

Keywords: family, love, God of mercy, Church that goes forth, conscience, pastoral care of accompanying and discernment.

* Prof. Ivan Šarčević, Ph. D., Franciscan Theology in Sarajevo, Aleja Bosne Srebrene 111, 71000 Sarajevo, Bosnia and Herzegovina, ivansarst@gmail.com 